Wyższa Szkoła Gospodarki Euroregionalnej

im. Alcide De Gasperi w Józefowie

\title{
EDUCATIONAL MODELS - BETWEEN HUMANISM AND COMMERCE
}

\section{MODELE EDUKACJI - MIĘDZY HUMANIZMEM \\ A KOMERCJĄ}

\begin{abstract}
Today's information society is characterized by new conditions of existence for people and organizations. It produces, collects, processes and uses information, which can be defined as the gradual emergence of the so-called knowledge society in which knowledge is a result of universal education. It is linked with the process of creating, transmitting and delivering knowledge. It is important to teach skills of learning and gaining knowledge. The sphere of education is a key to prepare society for new challenges and to solve problems of the modern world. One of them is the technological revolution, especially its information part. It is necessary to consider which education model would be best suited to fit the challenges of the 21 st century.

The article aims at identifying determinants of the development of the educational market from both demand and supply perspective. This market, like others, is becoming a global market, which means that this entails to both opportunities and threats. It shows different models of education and marketing tools used in the educational market.
\end{abstract}

\section{STRESZCZENIE}

Obecnie funkcjonujące społeczeństwo informacyjne charakteryzuje się nowymi warunkami działania ludzi i organizacji, produkuje, gromadzi, przetwarza i wykorzystuje informacje, co można określić jako stopniowe powstawanie społeczeństwa wiedzy, w którym wiedza, wypełniająca świadomość człowieka, jest rezultatem powszechnej edukacji, daje zdolność skutecznego zarządzania własnym rozwo- 
jem. Ma się do czynienia z procesem tworzenia, przekazywania i dostarczania wiedzy. Ważne jest zatem nauczanie umiejętności uczenia się i zdobywania wiedzy. W sferze edukacji znajduje się klucz do przygotowania społeczeństwa do nowych wyzwań i do rozwiązywania problemów współczesnego świata. Jednym z nich jest rewolucja technologiczna, a zwłaszcza jej część informacyjna. Należy rozważyć, jaki model kształcenia byłby najbardziej właściwy, odpowiadający wyzwaniom XXI wieku.

Artykułpoświęconyjest bardzo ważnej z punktu widzenia społeczeństwa obywatelskiego tematyce dotyczącej komercjalizacji (urynkowienia) usług edukacyjnych.

KEYWORDS: society, education, model, knowledge, markt

SŁOWA KLUCzOWE: społeczeństwo, edukacja, model, kształcenie, rynek

\section{WPROWADZENIE}

We współczesnym społeczeństwie jego rozwojowi towarzyszą ogromne zmiany mentalności związane przede wszystkim z postępem techniki i technologii. Za tym procesem musi nadążać szeroko pojęta edukacja, od najmłodszych lat do nawet późnej starości (Uniwersytety Trzeciego Wieku). Przed społeczeństwem XXI wieku stoją ogromne wyzwania cywilizacyjne i zmiany w codziennym życiu (Antczak, 2012). Jak temu sprostać? Jak dostosować system i model edukacji, aby tym wyzwaniom sprostać? W niniejszym artykule będzie miała miejsce próba odpowiedzi na te kluczowe dla każdego współczesnego społeczeństwa kwestie, zostaną przedstawione rozważania na temat podstawowych modeli edukacji, które dla uproszczenia nazwano humanistyczny i komercyjny oraz mieszany, jak również zmiany, jakie tym procesom towarzyszą.

Rozwinięte społeczeństwa XXI wieku, a szczególnie młodzi ludzie, prezentują konsumpcyjny styl i sposób życia (życie w cyberrzeczywistości, supermarkety, restauracje fast food, sklepy w cyberprzestrzeni itp.). Gwałtowny rozwój komercjalizacji i marketingu dotyczy również edukacji. Przewaga umiejętności nad wiedzą oznacza pewne zawężenie horyzontów oraz ograniczenie pełnego rozwinięcia uzdolnień właściwych dla każdego człowieka. Czy taka tendencja edukacyjna może spowodować negatywne skutki w przyszłości? Czy człowiek konsument, ,zmakdonaldyzowany” i wykształcony na McUniwersytetach potrafi być obywatelem? (Ritzer, 2009). Czy zagraża nam także 
nadmierna komercjalizacja usług edukacyjnych? Istotnym zagadnieniem wydaje się, by w obecnej pogoni za „klientem” nie zgubić tego, co wydaje się najważniejsze - czyli intelektualizacji nauczania i całościowej wizji kształcenia.

W Polsce (także w innych krajach postsocjalistycznych) następowały przyspieszone przemiany w zakresie modelu funkcjonowania i finansowania edukacji. Miało miejsce stopniowe odchodzenie od tradycyjnego modelu humanistyczno-państwowego do modelu komercyjno-zawodowego. W efekcie dokonała się transformacja, także systemowa, powstał rynek usług edukacyjnych. Nawet tradycyjne instytucje edukacyjne musiały się do tej zmiany, choćby w wymiarze konkurencyjnym - przystosować. Jedną z ważnych dróg wiodących ku temu jest marketing edukacyjny. Istotną kwestią jest stopień komercjalizacji (urynkowienia) oraz model funkcjonowania usług edukacyjnych. W niniejszym artykule proponuje się określenie i sprecyzowanie podstawowych założeń i cech dwóch modeli: modelu zorientowanego humanistycznie oraz takiego, który można określić jako komercyjny czy też rynkowy, i szukanie rozwiązania pośredniego (Antczak, 2015). Artykuł ma charakter analityczny, bazując na literaturze przedmiotu oraz wieloletnim doświadczeniu zawodowym autorki.

\section{MODEL HUMANISTYCZNY - NIEKOMERCYJNY}

Humanizm - traktowany jako pogląd na świat i postawa człowieka - był różnie postrzegany na przestrzeni wieków i przybierał rozmaite zabarwienia w zależności od epoki społeczno-historycznej, opcji światopoglądowej czy politycznej. Często używa się pojęcia „humanizm”, określając w ten sposób sprawy i pozycje dość różne, nie zawsze sobie równe. Odnosi się je najczęściej i tradycyjnie do intelektualistów renesansu oraz do idei humanizmu różnych stuleci i prądów, stosując to miano do uczonych, pisarzy i artystów, którzy wyróżniają się walorami osobistej kultury, przede wszystkim wrażliwością na losy ludzkie.

Korzenie humanizmu sięgają starożytności - przede wszystkim greckiej tradycji filozoficznej - paidei. Jej twórcami byli sofiści, Sofokles i Platon. Dokonali oni przełomu w kulturze umysłowej starożytnych Greków, polegającym na odkryciu praw rządzących ludzkim umysłem i ciałem. Człowiek był postrzegany jako istota wolna, ale nie wolnością woli, lecz wol- 
nością rozumu. Oznaczało to, że można kształtować ludzi, uczyć ich cnót, kształtować człowieczeństwo w człowieku przede wszystkim poprzez kontakt $\mathrm{z}$ dobrami kultury.

Etyka rzymska była kontynuacją greckiej. Specyfikę ludzkiej natury upatrywała w panującym nad afektami i popędami rozumie. Rzymianie używali określenia humanitas dla zaakcentowania konieczności wpajania obywatelowi wartości i uświadomienia powinności decydujących o jego człowieczeństwie.

Humanizm epoki renesansu uznaje człowieka za zdolnego kształtować świat, w którym jest dane mu żyć. Za manifest humanizmu uznaje się traktat „0 godności człowieka” Pico della Mirandoli, w którym stworzył pojęcie osobowości, a powstało ono, kiedy zaczęto coraz większą wagę przypisywać niepowtarzalności i wartości osoby ludzkiej (Pico Della Mirandoli, 2010). Humanizm odrodzenia ogłosił autonomię człowieka, jego prawo do wolności i do samodzielności myślenia. Humanizm nie negował Boga, ale bronił autonomii człowieka przed całkowitą zależnością od Kościoła. Dał on również początek nowoczesnego rozumienia narodowości i państwa oraz prawa wyznawania własnej wiary. Dalsze wieki przyniosły rozmaite zmiany w zakresie myśli filozoficznej, w dziedzinie sztuki i twórczości literackiej, myśli społecznej i naukowej, jak również w obszarze techniki, ekonomii i polityki.

Dziś kulturę pojmuje się nie tylko jako dziedzictwo, zbiór twórczych dokonań ludzkości w dziedzinie nauki i sztuki, lecz także za pomocą tego terminu określa się humanistyczną jakość ludzkich działań i sposobów życia. Kultura jest podstawową instancją edukacyjną, a edukacja to droga urzeczywistnienia kultury. Wielkim zadaniem współczesności jest pogłębienie w ludziach wartości empatycznych, czyli otwarcia na drugiego człowieka, i do zachowań prospołecznych wynikających z poczucia wspólnoty i więzi międzyludzkich. Konieczna wydaje się ochrona człowieka - humanisty przed agresją, w tym również polityczną, egoizmem i prymitywnymi postawami konsumpcyjnymi.

Termin humanizm wprowadził w 1808 r. F.I. Niethammer na określenie koncepcji pedagogicznej proponującej uznanie dziedzictwa kultury antycznej za podstawę wykształcenia i wychowania. Od 1859 r. mianem humanizmu określał G. Voit kulturę renesansu europejskiego (XIV-XVI wieku). Współ- 
czesne rozumienie humanizmu jest wieloznaczne i łączone $\mathrm{z}$ takimi uniwersalnymi kategoriami, jak: życie, człowiek, kultura, przyroda, wszechświat itp. Jednocześnie terminu tego używa się w wąskim, tradycyjnym znaczeniu na określenie zawodów (dzielenie ludzi na humanistów, przyrodników, techników itp.), to nie powinno przesłaniać zasadniczego znaczenia rozciągającego się na potrzeby, postawy, orientacje i poglądy ludzi na świat i życie.

Kształcenie humanistyczne powinno wyrabiać wiedzę osobistą, czyli umiejętność rozumienia zjawisk, szerszego wyeksponowania w kształceniu współczesnej młodzieży zagadnień związanych z dniem dzisiejszym, ze współczesną kulturą w najszerszym tego słowa znaczeniu. Nie można więc w kształceniu ograniczyć się do obszarów nauk ścisłych - tak ważnych we współczesnym świecie, ale uwzględnić także nauki społeczne i humanistyczne oraz edukację obywatelską. Istotne jest kształcenie jasności myślenia i komunikowania, otwartości umysłu na argumenty i racje innych, bezstronności, umiejętności poszukiwania prawdy. Humanizm to ogół idei i wartości, postaw i czynów służących człowiekowi. Za pomocą terminu „humanizm” określa się też stosunki międzyludzkie, stosunek ludzi do świata zwierząt i rzeczy. Używa się tego terminu nie tylko w odniesieniu do specjalistów w dziedzinie filologii, filozofii, religii, lecz także do uczonych innych dziedzin nauki, którzy reprezentują wysoką kulturę i wrażliwość na losy ludzi.

W pedagogice humanizm stanowi dla wielu pedagogów ideał wychowania, w którym eksponuje się wagę integralnego i wielostronnego rozwoju wychowanka zarówno w sferze somatycznej, psychicznej, jak i duchowej. W związku z tym konieczny jest udział różnych środowisk: biznesu, partii politycznych, organizacji naukowych i edukacyjnych, kościołów. Nie może człowiekowi wystarczyć edukacja szkolna czy nawet akademicka dla rozwiązywania jego życiowych problemów. Wobec wręcz rewolucyjnego postępu wiedzy, nauki i techniki nie ma jednego, doskonałego, wystarczającego „dyplomu na całe życie” (szerzej Zacher, Antczak, 2003).

\section{MODEL KOMERCYJNY - RYNKOWY}

Model rynkowy koncentruje się wokół następujących zasad i założeń:

- indywidualistyczny system wartości;

- rynek reguluje zachowania jednostek i gospodarki; 
- ważna jest wolność ekonomiczna;

- ludzkie zachowania są zorientowane na sukces i na konsumpcję;

- edukacja jest prywatną sprawą człowieka;

- pozytywną rzeczą jest urynkowienie i komercjalizacja wszystkiego (także edukacji);

- rola państwa powinna być marginalna. Zasady te przypominają hasło leseferyzmu ${ }^{1}$ charakterystyczne dla koncepcji liberalizmu ekonomicznego Francji początku XIX wieku i rozpowszechnione na inne kraje.

Również współcześnie szereg państw opiera politykę gospodarczą na zasadach liberalizmu, a tendencje liberalne pojawiły się w Polsce od 1989 r., ze zmiennym nasileniem, działaniach różnych ekip rządowych. Fundamentami koncepcji liberalnej są:

1. Indywidualizm - uznanie jednostki za absolutny punkt odniesienia refleksji nad porządkiem społecznym, co wyraża się poprzez pojęcie wolności (autonomii) jednostek. Wszystkie jednostki są równe w swej wolności, wszyscy mają równe prawa. Liberalna koncepcja społeczeństwa zakłada uznanie pluralistycznego i policentrycznego charakteru porządku społecznego.

2. Szeroko rozumiane prawo własności, czyli przyznanie każdej jednostce prawa do posiadania pewnej ograniczonej, ale bezwzględnie nienaruszalnej przestrzeni prywatnej. Jednostka ma prawo robić ze swoją własnością wszystko, co uzna za stosowne.

3. Wolność działania w sferze publicznej, co oznacza, że jednostka realizuje siebie i swoją wolność, urzeczywistniając swoim działaniem to, co jest dla niej ważne - to, co rozumie jako swój istotny interes. Będzie to więc wolność działania rozumiana jako swoboda poruszania się, wyboru zawodu, wolności słowa, zrzeszania się. Państwo - jako instrument, który ma służyć interesom jednostek, być strażnikiem nienaruszalności sfery prywatnej i gwarantem poszanowania równej wolności w sferze publicznej.

Postulat ograniczonego państwa - uwzględnienie i przeciwdziałanie możliwości, kiedy ktoś- jednostka lub grupa ludzi - wykorzystując moc 
państwa, zechce pozbawić pozostałych równej wolności, aby ten, kto pełni funkcję strażnika, nie stał się zagrożeniem dla tych, których ma strzec. Określa się więc ściśle zakres działania państwa, który ma się ograniczyć do ochrony sfery prywatnej obywateli i gwarantować wynikające z niej elementarne prawa oraz pilnować przestrzegania powszechnie obowiązujących procedur.

Liberalizm jest teorią i metodą dążenia do budowy mechanizmów społecznych umożliwiających zaistnienie różnic, wielości, antynomii. W perspektywie liberalnej społeczeństwo obywatelskie to suma niezależnych i ruchliwych jednostek zajmujących się swoimi prywatnymi sprawami ekonomicznymi i wyposażonych w tzw. prawa człowieka. $Z$ tego wynika postulat państwa minimum, stojącego na straży indywidualnych uprawnień. Liberalna tradycja myślenia o społeczeństwie obywatelskim ma pochodzenie nowożytne, a za jej źródło przyjęto uważać filozofię polityczną Johna Locke’a. Podstawą liberalizmu jest separacja społeczeństwa i państwa. Idea społeczeństwa obywatelskiego (buergerliche Gesellschaft) odgrywa istotną rolę w myśli politycznej Kanta, Hegla i Marksa, lecz jest traktowana przez tych filozofów w odmienny sposób. Kant dostrzega związek między społeczeństwem obywatelskim a wolnością, równością i niezależnością. Stanowi ona dla niego gwarancję społecznej mobilności i postępu. Uważa on, że sami, działając w zgodzie z przyjętymi zasadami, kształtujemy społeczeństwo obywatelskie, dostosowując je do naszych celów. Dla Kanta jest to społeczeństwo kształtowane przez ludzkie cele i dzięki wzajemności, opartej na prawie, stwarza możliwości wolnego i godnego życia (Kant, 1995).

U Hegla i Marksa to raczej społeczeństwo obywatelskie wywiera wpływ formatywny i określa zasady. Według Hegla należy zatem wzmocnić społeczeństwo obywatelskie, natomiast wolność zostaje ograniczona, gdyż społeczeństwo obywatelskie staje się sferą gospodarczego egoizmu i dyslokacji (Hegel, 1969). U Marksa nie ma się do czynienia z normami cywilizacji, gdyż społeczeństwo burżuazyjne jest tylko przykrywką dla powszechnej alienacji i wyzysku (Marks, Engels, 1969).

W XVIII wieku coraz istotniejsze stawały się prawa własności, wolnej przedsiębiorczości i wymiany handlowej. W XIX wieku narastało znaczenie wolności słowa, zrzeszania oraz praw socjalnych. Od połowy XX wieku, 
w ścisłym związku z ogromnym rozwojem gospodarki, technologii i medycyny oraz postępującą dehelenizacją i dechrystianizacją, zwycięża w liberalizmie koncepcja praw całkowicie naturalnych wobec różnych dóbr i celów, do jakich człowiek powinien dążyć. Obecnie ma się do czynienia z tak zwanym postępowym nurtem liberalizmu, pozbawionym idei państwowej, retorycznie traktującym ideę podziału władz.

Liberalizm jest zarówno doktryną filozoficzną, jak i ekonomiczną, polityczną, społeczną, a wszystkie te dziedziny poznania i życia wzajemnie oddziałują na siebie. Filozofia wolności i podstawowego znaczenia jednostki, jej dążeń i chęci osiągnięcia w życiu, co jest dla niej istotne, kluczowe i decydujące, jest ważną doktryną życiową. Spełnienie tych dążeń, niezależnie od możliwości i kosztów, jest podstawową cechą współczesnego społeczeństwa. W gospodarce rynkowej każde dobro lub usługa jest produktem i podlega prawom rynku, a więc działaniom nastawionym na zysk, na zaspokojenie oczekiwań klienta, spowodowanie jego satysfakcji - powstaje pojęcie komercjalizmu. Jest to postawa, postępowanie polegające na liczeniu się tylko z tym, co daje zysk. Oznacza to oparcie wszelkiej działalności na zasadach handlowych (dochodowych), często ze szkodą dla jakości.

W literaturze znane jest pojęcie makdonaldyzacji społeczeństwa, którego twórcą i analitykiem jest George Ritzer. Twierdzi on, już od szeregu lat, że pojawiło się na horyzoncie coś, co zastąpi racjonalizację (w Weberowskim rozumieniu) i jej ostateczną formę - biurokrację, a tym czymś jest restauracja szybkich dań - McDonald's, która zrewolucjonizowała nie tylko branżę gastronomiczną, lecz także społeczeństwo, najpierw amerykańskie, a po nim cały świat. Makdonaldyzacja cechuje nie tylko gastronomię, lecz także sposób, w jaki uprawia politykę, zdobywa się wykształcenie, podróżuje, spędza czas wolny, odżywia, traktuje rodzinę - każdą dziedzinę życia społecznego (Ritzer, 2009). Zjawisko to oparte jest na czterech wyznacznikach, proponowanych klientom, personelowi oraz menadżerom:

1) efektywność (optymalna metoda przejścia od jednego punktu do następnego - zapewnienie najlepszego sposobu zaspokajania głodu);

2) kalkulacyjność (dobre jest to, co dostajemy prędko i w dużej ilości. Zwraca się uwagę na ilość, a nie na jakość, tym bardziej że jest ona z góry określona); 
3) przewidywalność (gwarancja, że towary i usługi będą wszędzie i zawsze takie same);

4) możliwość manipulacji (zastąpienie technologii ludzkiej, technologią niewymagającą udziału człowieka. McDonald’s manipuluje tymi, którzy wkraczają w jego świat i może zagwarantować klientom, że w jego bramach nie spotka ich żadna niespodzianka).

W istocie kluczową normą wszelkiej działalności jest ilość, i to duża - wręcz staje się surogatem jakości. Kładzenie nacisku na ilościowe ujmowanie zjawisk ma miejsce w różnych dziedzinach życia, także oczywiście w edukacji. Obserwuje się (od kilku lat również w Polsce) skupienie uwagi na ilości przyjętej młodzieży do szkoły różnych szczebli, nie zaś na tym, czego się faktycznie uczą i jakie przeżycia intelektualne temu towarzyszą. Oczywiste jest, że postęp techniki może prowadzić do dehumanizacji w nauczaniu. W niektórych krajach, już obecnie, występuje duża dehumanizacja - rosnące eliminowanie nauczyciela, a co za tym idzie - zerwanie jakichkolwiek kontaktów między nauczycielem a studentem (uczniem). Jeśli doda się do tego komputerowe przygotowanie i sprawdzanie testów, wpajanie od najmłodszych lat różnych regulaminów i standardów zachowań z jednej strony oraz dostosowywanie się rynku edukacyjnego do oczekiwań „klientów”, po to aby zdobyć zaufanie i przyciągnąć znaczne ich ilości - z drugiej - otrzyma się obraz współczesnej szkoły. Skomercjalizowane szkolnictwo sprowadza się najczęściej do powszechnie obowiązującej formuły:

- dla klienta - tanio,

- dla społeczeństwa - masowo,

- dla właścicieli - z dużym zyskiem.

Tak naprawdę nie jest istotne, czego, jak i kto uczy, lecz zdobycie dużej liczby „klientów” i zorganizowanie procesu dydaktycznego tak, aby osiągnąć maksymalny zysk oraz bezkrytycznie zaspokoić oczekiwania odbiorcy usługi edukacyjnej. Wszystko to może prowadzić do ograniczenia i spłycenia treści kształcenia, „produkowania” wąskoprofilowych specjalistów oraz w efekcie do obniżenia ogólnego poziomu wykształcenia społeczeństwa (szerzej Antczak, 2011). 


\section{WIEDZA W XXI WIEKU - MODEL MIESZANY}

Oczywiście, oba powyżej przedstawione modele to w zasadzie „typy idealne", zbudowane w dużej mierze na zasadzie przeciwieństwa cech. W sensie historycznym model humanistyczny poprzedzał model rynkowy, którego przyspieszony rozwój obserwuje się w ostatnich kilku dekadach. Ważny jest nie tylko historyczny, lecz także aktualny oraz przyszłościowy kontekst funkcjonowania tych modeli, czy raczej ich „mieszanek” (w różnych proporcjach). Kontekst ten to współczesne zmiany cywilizacyjno-kulturowe, między innymi globalizacja. Procesom tworzenia cywilizacji globalnej, wprowadzaniu do naszego życia codziennego rewolucyjnych osiągnięć technicznych i technologicznych (komputery, internet itp.) towarzyszy zjawisko „spłaszczenia” i erozji społeczno-kulturowej (Szejniuk, 2013). Można więc zapytać, jaka jest cena dokonującego się awansu cywilizacyjnego? Wśród młodzieży coraz bardziej rozpowszechnia się agresja, konsumpcjonizm (zasada „mieć”), zbrutalizowana rozrywka, a w wyniku frustracji ucieczka w świat nierzeczywisty (narkotyki, dopalacze). Kryzys autorytetów osób, instytucji, ruchów społecznych i partii politycznych utrudnia poszukiwanie wzorów oraz walkę o ich obecność w codziennym życiu. Rodzina, szkoła czy też Kościól, nie tylko w Polsce, utraciły siłę swoich wpływów na rzecz grupy rówieśniczej i mass mediów. Wzorem zachowania staje się życie o charakterze konsumpcyjnym oraz w wirtualnym świecie. We wszechotaczającym nas konkurencyjnym świecie chodzi o to, by zaspokoić - szybko i dobrze - zgłaszane przez konsumenta potrzeby, oraz tworzyć nowe (często sztuczne) potrzeby (Novikowa, 2016). Czy jednak edukacja powinna podporządkować się takim regułom? Oto ważne pytanie, nie tylko badawcze, lecz także praktyczne.

Wydaje się, że szkoły (różnych szczebli), świadczące usługi edukacyjne, nie są i nie mogą być wyłącznie instytucjami rynkowymi, przede wszystkim dlatego, że mają one specyficzną misję edukacyjną, tzn. - obok przekazywania wiedzy - wychowanie, będące podstawą rozwoju społecznego, obywatelskiego i kulturowego. Powinno to dotyczyć nie tylko sfery publicznej (gdzie edukacja jest dobrem powszechnym), lecz także prywatnej (komercyjnej). Do pierwszej z nich zalicza się państwowe placówki oświatowe, tworzące jeden $\mathrm{z}$ obszarów organizacji niekomercyjnych (non profit). W tym obsza- 
rze, biorąc pod uwagę utrzymujący się wśród dzieci i młodzieży od wielu lat niż demograficzny, coraz rzadziej ma miejsce przewaga nadrzędnych zadań społecznych w stosunku do ekonomicznych motywów funkcjonowania edukacji. Coraz częściej realizowane niekomercyjne cele społeczne są związane z konkurowaniem - rywalizacją organizacji między sobą. Zabiegają przede wszystkim o lepiej przygotowanych kandydatów do dalszej nauki i o to, by utrzymać zatrudnioną kadrę, a będzie to możliwe przy zapewnieniu odpowiedniej liczby uczniów/studentów. Drugą grupę organizacji tworzą jednostki oferujące płatne usługi edukacyjne, często takie, których nie ma w ofercie sfery publicznej lub ich przewaga polega na łatwości dostępu i lepszym dostosowaniu do aktualnych potrzeb pracodawców (głównie biznesu).

Każdy ze wspomnianych modeli ma oczywiście swoją „czystą” postać, lecz w praktyce nigdy w takiej formie one nie występują. Przejście z epoki industrialnej do postindustrialnej - do jej fazy informacyjnej - wymusza uwzględnienie w modelu zorientowanym humanistycznie realiów współczesnego świata, związanych z niezwykle szybkim postępem cywilizacyjnym, który cechuje między innymi:

- szybki wzrost konsumpcji dóbr materialnych;

- wzrost wydajności pracy dzięki nowej technice i stopniowa minimalizacja wysiłku fizycznego;

- wypieranie człowieka przez technikę.

W „czystym” modelu komercyjnym zakłada się maksymalne urynkowienie sektora edukacji. Człowiek, wraz ze swoim wykształceniem, ma odpowiadać na zgłaszane przez rynek pracy (de facto pracodawców) potrzeby, ma dostosować się właśnie do tych wymogów, czyli ma spełniać oczekiwania sfery biznesu, administracji i innych sfer, być elementem rynku traktowanym dość instrumentalnie. Istnieją jednak ważne dla jednostki ludzkiej wartości. Wraz z rozwojem cywilizacyjnym człowiek odczuwa również potrzebę samorealizacji (piramida Maslowa) i rozwijania własnych zainteresowań, niekoniecznie zbieżnych $\mathrm{z}$ wykonywaną pracą zawodową, zdobytym wykształceniem czy też oczekiwaniami rynku i pracodawców. Stąd niebywała popularność Uniwersytetów Trzeciego Wieku, w których można rozwijać swoje pasje. 
Najbardziej racjonalnym i do zaakceptowania przez podmioty działające na rynku wydaje się model mieszany, który uwzględnia zalety obu modeli (unikając przy tym ich słabości). Modele te mogą się różnić między sobą wpływem każdego z modeli podstawowych.

\section{Podsumowanie}

Postrzeganie edukacji jako usługi stało się w Polsce nowym zjawiskiem w okresie transformacji systemowej (lata 90. ubiegłego stulecia). Zaczęto zatem postrzegać na rynku usług edukacyjnych (w ujęciu instytucjonalnym obejmuje on: przedszkola, szkoły podstawowe, gimnazja, szkoły ponadgimnazjalne, szkoły policealne, szkoły wyższe, różne formy dokształcania), występowanie, tak jak na każdym innym, podstawowych elementów: podaży (liczba placówek edukacyjnych oraz ich „moc przerobowa”, jak również ich oferty) i popytu (ilościowo-jakościowe zapotrzebowanie na usługi edukacyjne) określanego między innymi przez strukturę demograficzną ludności, poziom zamożności społeczeństwa, poziom aspiracji rodziców i dzieci. Specyfika tego rynku polega przede wszystkim na tym, że:

- organizacje świadczące usługi edukacyjne nie mogą być instytucjami wyłącznie rynkowymi, ponieważ mają one specyficzną misję edukacyjna, to znaczy - obok przekazywania wiedzy - wychowanie, jako fundament rozwoju społecznego i kulturowego, a misja ta dotyczy człowieka - nie tylko jako konsumenta, lecz także jako osobowości i jako obywatela;

- decyzje dotyczące wyboru instytucji edukacyjnej (na każdym poziomie kształcenia), często mają one wpływ na dalszą drogę życiową, efekty dokonanych wyborów można zaś ocenić dopiero w późniejszym okresie (często po kilku latach);

- ma tu miejsce kształtowanie człowieka, jego osobowości, charakteru, postawy od najmłodszych lat (Antczak, 2011).

Czy można zatem, bez żadnych ograniczeń, stosować znane metody marketingowe w odniesieniu do edukacji? Marketing w tej dziedzinie opiera się przede wszystkim na przekazywaniu informacji o usłudze; sprawdzenie jej rzetelności i wiarygodności jest jednak trudne. Dlatego też istotny staje się problem uczciwości, moralności osób zajmujących się marketingiem w edukacji. 
Obecnie największy nacisk w reklamach kładziony jest na wyposażenie, kadrę nauczającą, kontakty z zagranicą, miejsce szkoły w rankingach. Mało mówi się natomiast o rzeczywistym „produkcie”, jakim jest sama edukacja, jej programy, metody i treści nauczania oraz faktycznie zdobyta wiedza i umiejętności. Ten właśnie „produkt” kształtuje człowieka w jego całościowym funkcjonowaniu. Postępujące urynkowienie znaczącej części usług edukacyjnych nie powinno zatem niweczyć humanistycznej misji edukacji.

\section{Literatura}

Antczak, B. (2015). Ustugi edukacyjne - misja czy komercja?, „Journal of Modern Science" 1/24. ISSN 1734-2031.

Antczak, B. (2012). Współczesne tendencje tworzenia, dyfuzji i wykorzystania wiedzy, [w:] Dylematy współczesnej edukacji, Józefów: WSGE. ISBN 9788362753185.

Antczak, B. (2011). Usługi edukacyjne - rynek taki sam jak inne?, Józefów: WSGE. ISBN 9788362753123.

Gross-Gołacka, E., (2008). Równowaga praca-życie a strategia zarządzania zasobami ludzkimi, [w]: C. Sadowska-Snarska (red.) Równowaga praca-życie-rodzina, Białystok: Wyższa Szkoła Ekonomiczna w Białymstoku. ISBN 9788387981730.

Gross-Gołacka, E. (2016). Rola koncepcji zagadnienia różnorodnością w doskonaleniu organizacji, „Problemy Jakości” nr 4, s. 28-34. ISSN 0137-8651.

Hegel, G.W.F. (1969). Zasady filozofii i prawa, Warszawa: PWN.

Kant, L. (1995). O porzekadle. Do wiecznego pokoju, Toruń: COMER. ISBN 8385149465.

Marks, K., Engels, F. (1969). Manifest komunistyczny, Warszawa: Książka i Wiedza.

Mirandoli, P. (2010). O godności człowieka, Warszawa: Instytut Wydawniczy PAX. ISBN 9788376830162.

Novikowa, K. (2016). Informacja, wiedza, technologia w wybranych koncepcjach zmiany społecznej, „Journal of Modern Science” 2/29, ISSN 1734-2031.

Ritzer, G. (2009). McDonaldyzacja społeczeństwa, Warszawa: Muza S.A. ISBN 9788374956079.

Szejniuk, A. (2013). Społeczna odpowiedzialność biznesu instrumentem autorytetu organizacji wśród społeczności lokalnej, [w:] Autorytet w wychowaniu i edukacji, Józefów: WSGE. ISBN 9788362753321. 
Zacher, L.W., Antczak, B. (2003). Edukacja - między misją a komercją, [w:] Edukacyjne problemy czasu globalizacji, Białystok: Wydawnictwo Uniwersytetu Białostockiego. ISBN 8389190176.

\section{Endnotes}

${ }^{1}$ Laissez-faire - francuskie określenie, które znaczy: pozwólcie działać (zostawcie nas w spokoju); wyrażające podstawową zasadę liberalizmu gospodarczego, hołdującą swobodzie gospodarczej jednostek, wolnej konkurencji i nieingerencji państwa w gospodarkę. 